\title{
PROFESSIONAL SURVIVAL IN TEACHING ENGLISH IN INDONESIA
}

\author{
V. Luluk Prijambodo \\ Faculty of Teacher Training \& Education \\ Widya Mandala Catholic University Surabaya \\ vielpi@ukwms.ac.id
}

\begin{abstract}
Teaching English as a foreign language (TEFL) in Indonesia offers not only challenges but also reward. Some teachers perceive the challenges as the professional consequences for their determination to be English teachers. Such a perception leads them to the enjoyment and optimism toward their sustainable professional development or career escalation. Some others consider the challenges as such a heavy burden of life that they feel unmotivated to elevate their professional development. In this era of education standardization, teachers are faced with two dichotomous options: satisfying the standard optimally in order to deserve the professional rewards or benefits or just fulfilling it minimally and accordingly miss the career advancement and the professional reward. This paper shares the ideas of what English teachers need to do to survive professionally in their English teaching and gain the professional benefits offered.
\end{abstract}

Keywords: profession, professional survival, professional standard, teacher competence

\section{INTRODUCTION}

In this globalization era, it is very relevant to claim that English language opens the access to the world network. As the "global language" (Crystal, 2003: 3 ), English, which achieves a genuinely global status and develops a special role in the countries of its speakers, walks side by side with globalization towards the goal of communication, business, and politics. This status makes English a strategic language to learn and master.

An individual learning English may be driven by his/her instrumental or integrative motivation. Gardner and Lambert (1972), cited in Brown (2007: 170), identify it as "instrumental and integrative motivations". The former refers to "acquiring a language as a means for attaining instrumental goals: furthering a career, reading technical material, translation, and so forth." The latter refers to the learners' attempt "to integrate themselves into the culture of the second language group and become involved in the social interchange in that group."

Between the two kinds of motivation, most Indonesian learners learn English under their instrumental motivation. They learn English as a foreign language to support them to search for a better job and develop their career. They 
study English formally at school or non-formally at an English course, and even some of them continue studying English formally at a college. Their English communicative competence opens them more accesses to select more promising jobs such as digital copywriter, editorial assistant, journalist, writer, publishing copy-editor/proofreader, librarian, advertising account executive, administrator, information officer, marketing executive, public relations officer, or school teacher.

The fact that English communicative competence opens more access to better jobs causes some of those who study English formally at the English Education Study Program prefer not to be English teachers after their graduation. Instead, they prefer other professions to teaching. This happens to the writer's students at his university and may also happen to the other students of the other universities. When addressing a question about the intention to be an English teacher to the students who have just finished their Teaching Practice Program held by the Micro Teaching Laboratory, Faculty of Teacher Training and Education in his university, for instance, the writer found that only 13 out of 33 (39\%) students were motivated to be English teachers. They are interested to be English teachers since teaching English is their passion. In contrast, the rest of the students ( 20 out of 33 students or $61 \%$ ) are not interested to be English teachers though they realize that their department prepares them to be professional English teachers. They perceive teaching as a hard, more demanding profession which does not pay them well.

A study by Jobplanet (Kompas.com, 3 May 2016) as issued in the end of April 2016 to celebrate the National Education Day (2 May 2016) examined the level of working satisfaction and average salary of 6,250 workers of some educational institutions in Indonesia. Some factors under analysis are career ladder, salary and incentive, work-life balance, corporate culture, and management factor. The study reveals that salary and incentive scored the lowest (2.79), management factor scored 2.89, workers' satisfaction level toward career ladder scored 2.91, work-life balance scored 3.07, and corporate culture scored3.27 (the highest factor score), which is still relatively far from the highest score (5.0). This finding indicates that though work-life balance and corporate culture of educational institution workers are relatively satisfying, the salary is not yet satisfying.

From 3,473 respondents who were teachers of elementary schools, junior high schools, senior high schools, private teachers, foreign language courses teachers, and lecturers, it can be informed that the average salary of Indonesian lecturers is $\mathrm{Rp} 3,326,700$ per month, foreign language course teachers $\mathrm{Rp}$ $2,656,300$, elementary to senior high school teachers $\mathrm{Rp} 2,530,350$, kindergarten teachers $\operatorname{Rp} 2,292,200$, and private teachers $\mathrm{Rp} 2,188,500$, respectively. This fact fails to hide that the salary of the teachers or lecturers in Indonesia is relatively not that satisfying, except if they become civil-servant teachers or lecturers. This relatively unsatisfying salary may create such a negative branding for teaching as a profession that not many English education study program graduates are interested to be English teachers.

Another study by Jobplanet (Kompas.com, 25 July 2016) on the level of employee working satisfaction in Indonesia, which involved 48,250 employees and a sample of 18,900 companies from various industry sectors in Indonesia, 
found that the employees with the highest level of satisfaction are those working in governmental institutions such as civil servants $(P N S)$, social service workers, and members of the police and army with the average job satisfaction rate of 3.70, placing the first position in rank. Two main reasons for this rate are allowances and old age guarantees given to the government officials. The next position is placed successively by the employees of media and public relations sector with the average job satisfaction rate of 3.59, research and development sector (3.57), public services sector (3.52), business development sector (3.51), legal sector (3.51), professional workers (3.50), information technology sector (3.49), engineering sector (3.47), and marketing sector (3.46). The fact that those working in governmental institutions attain the highest level of satisfaction strengthens the fact that becoming civil-servant English teachers or lecturers is more promising than the non-governmental ones.

Apart from the reality as described above, as long as the teaching profession is perceived as more than a job, a "calling", or a "vocation" (Gulti, 2010: 14, see also Farrell, 2015, pp. 52-53), English teaching can still be considered as a promising profession since it offers professional benefits beyond its challenges. This paper shares the ideas of what English teachers need to do to survive professionally in their English teaching so that they deserve their professional rewards.

\section{TEACHING AS A PROFESSION}

The term profession, in general, can be defined as any type of work which is "represented as having a strong technical culture with specialized body of knowledge gained through an extended period of advanced training" (Cobbold, 2015: 126). The agent of the profession, or professionals, according to Hargreaves (2000) and Hoyle \& John (1995) cited in Cobbold (2015: 126), have shared standards of practice; a high degree of autonomy in taking decisions relating to their practice; and a service ethic that commits them to provide skilled service, over which they wield a firm monopoly, to clients in return for a stipulated fee. Similarly, Furlong et al (2000: 5) who argue that the three concepts of knowledge, autonomy and responsibility are interlinked and vital to a conventional idea of professionalism, explain:

It is because professionals face complex and unpredictable situations that they need a specialized body of knowledge; if they are to apply that knowledge, it is argued that they need the autonomy to make their own judgments. Given that they have autonomy, it is essential that they act with responsibility collectively they need to develop appropriate professional values.

In Indonesia, teaching as profession has gained its legitimate recognition since 2005 when Law of the Republic of Indonesia Number 14 Year 2005 Concerning Teachers and Lecturers was issued to public. Article 1 Section 1 of this law states, "(1) Teachers are professional educators with the main task of educating, teaching, guiding, directing, training, assessing, and evaluating learners on formal early childhood education, primary education, and secondary 
education." (p.2). Then Article 2 Section 2 of this law states, "(2) The recognition of the position of the teacher as professional ... is proved by the teaching certificate." (p.4). These two legal clauses reflect the demand beyond the notion of profession and professional.

Thus, given status as professionals, teachers in Indonesia, including English teachers, have to be ready to satisfy the professional requirements in order to receive their professional rights. Accordingly, the teachers are demanded to carry out their professional tasks in accordance with the professionalism principles as stated in the same law (Article 7 Section 1) as follows:

(1) Teachers and lecturers are a special field of work performed on the following principles:

a. Having talents, interests, calling souls, and idealism;

b. Having commitment to improve the quality of education, faith, piety, and noble character;

c. Having academic qualifications and educational background in line with the task field;

d. Having competencies relevant with the task field;

e. Having responsibility for the implementation of professional tasks,

f. Earning income in accordance with work performance;

g. Having the opportunity to sustainably develop professionalism through lifelong learning;

h. Having legal protection in performing professional duties; and

i. Having a professional organization with the authority to regulate teacher (p. 6)

\section{SATISFYING THE PROFESSIONAL STANDARD}

Once an individual has decided to be an English teacher, he or she has to follow the above principles. First of all, he or she has to make sure that his/her decision to be a teacher, an English teacher, is not an accidental choice, but as a calling or a vocation. This is important to confirm since his/her choice to be an English teacher will affect his/her seriousness in fulfilling the professional requirements in order to make him/her survive professionally. Professional development, according to Gulti (2010: 38), focuses on taking teaching responsibilities seriously (intrinsic motivation). Gulti (2010: 15) furthers argues, "Extrinsically motivated teachers will tend to relate to teaching primarily as a job; they are less likely to see difficulties as challenges, and are therefore more likely to find their motivation weakening in the face of problems."

The second professional standard an English teacher has to fulfill is to have academic qualification required. Regulation of the Minister of Education and Culture Number 16 Year 2007 Concerning the Standard of Academic Qualification and Teacher Competencies, Article 1 Section 1 states, "Each teacher must meet national academic qualification and teacher competence standard" (p.2). The academic qualification is obtained through higher education (S1) or undergraduate diploma (D-IV) programs. Thus, an English teacher who has not been S1 or D-IV diploma holder has to continue his/her study first to get the 
required diploma. The educational statistics year 2016/2017 as shown in the table below (see further Center for Data and Statistics of Education and Culture, Ministry of Education and Culture, 2017) indicates this phenomenon.

Number of Principals + Teachers in All Provinces

According to Their Highest Diploma Year 2016/2017

\begin{tabular}{|c|l|c|c|c|}
\hline No. & \multicolumn{1}{|c|}{ School Level } & $<$ S1 & $\geq$ S1 & Total \\
\hline 1 & Kindergarten & $\begin{array}{c}157,026 \\
(47.71 \%)\end{array}$ & $\begin{array}{c}172,076 \\
(52.29 \%)\end{array}$ & 329,102 \\
\hline 2 & Elementary School & $250,453(15.79)$ & $\begin{array}{c}1,335,674 \\
(84.21 \%)\end{array}$ & $1,586,127$ \\
\hline 3 & Junior High School & $49,147(7,89 \%)$ & $\begin{array}{c}573,634 \\
(92,11 \%)\end{array}$ & 622,781 \\
\hline 4 & Senior High School & $9,202(3.12 \%)$ & $\begin{array}{c}285,670 \\
(96.88 \%)\end{array}$ & 294,872 \\
\hline 5 & Vocational High & $16,686(6.04 \%)$ & $\begin{array}{c}259,413 \\
(93.96 \%)\end{array}$ & 276,099 \\
\hline
\end{tabular}

When an English teacher has had the academic qualification, he/she is expected to be more committed to continue developing his/her professionalism or teaching competences in order to be more capable in carrying out his/her professional tasks. That is why he/she has to join teacher certification-another professional standard. Government Regulation Number 19 Year 2017 on Amendment to Government Regulation Number 74 Year 2008 Concerning Teachers, Article 1, Section 3, states, "Certification is the process of granting a teacher a teaching certificate" (p.4). Then in Section 4, it is stated, "Teaching certificate is formal evidence as recognition given to a teacher as a professional" (p. 5). Thus, based on this regulation, English teachers have to spend some of their time and energy to join certification to obtain their teaching license, their formal evidence as professionals. By this, they are legally protected in performing their professional duties. Concerning professionalism, Ingersoll \& Perda (2008: 108) say that entry into professions requires credentials. That is, entry into professions typically requires a license, which is obtained only after completion of an officially sanctioned training program and passage of examinations.

Besides for granting teachers formal evidence as professionals, teacher certification is intended "... as a fulfillment of the requirement for teachers to meet the pedagogic, personality, social, and professional competences as stipulated in Law Number 14 Year 2005 Concerning Teachers and Lecturers" (Regulation of the Minister of Education and Culture Number 29 Year 2016 Concerning Certification for Teachers Appointed Before 2016, Article 2, Section 2 states, p. 2). Further, in Article 4 of this regulation, it is stated that to join the certification, a teacher has to satisfy the requirements needed as follows:

a. having an undergraduate academic qualification (S-1) or diploma four (D-IV); 
b. having status as a civil-servant teacher candidate (CPNS), civil servant, or permanent teacher;

c. having a unique number of teacher and education personnel (NUPTK);

d. having been registered in the main education list of the ministry of education and culture; and

e. having participated in the teacher competency exam (UKG) before attending teacher professional education and training (PLPG), particularly for teachers who were appointed after Law Number 14 Year 2005 Concerning Teachers and Lecturers is valid until 31 December 2015 are required to have a minimum score of 55 for their UKG. (p.3)

Through the certification, a teacher is expected to develop further the four aspects of teacher competences: pedagogic, personality, social, and professional. Competence, in Law Number 14 Year 2005 Concerning Teachers and Lecturers, Article 1 Section 10, is defined as "a set of knowledge, skills, and behavior that must be owned, internalized, and mastered by teachers or lecturers in performing their professional tasks" (p. 16). In Government Regulation Number 74 Year 2008 Concerning Teachers, Article 3 Section 4), pedagogic competence is defined as "teacher competence in managing the learning of learners...", and professional competence is defined as "teacher competence in mastering the science, technology, and/or art and culture related the subject taught ..." (Article 3 Section 7).

Pedagogical competence, as elaborated in the Attachment of the Regulation of the Minister of National Education Number 16 Year 2007 Concerning Standard of Academic Qualification and Teacher Competence, includes the abilities to understand well the learners' physical, moral, social, cultural, emotional, and intellectual aspects; to master the learning theories and principles; to develop a curriculum of the subject he/she teaches; to organize educational activities; to utilize ICT in their his/her teaching; to facilitate learners to develop their potentials optimally; to communicate with learners effectively, empathically, and politely; to conduct assessment and evaluation on learning processes and outcomes; to make use of assessment and evaluation results for learning purposes; and to make reflections for learning quality improvement. For the English teachers who did not graduate from the English education study program, developing pedagogical competence needs special energy since they have never studied such a course during their study at college. For the English teachers who graduated from the English education study program, joining certification stimulates them to refresh and develop their pedagogical competence further.

The second competence, that is personality competence, includes the abilities to behave in accordance with the norms of religion, law, social life, and national culture of Indonesia; to show oneself as an individual with honesty and noble character and as role model for learners and society; to show oneself as a steady, stable, mature, wise, and authoritative person; to demonstrate work ethic, high responsibility, self-pride in being a teacher, and self-esteem, and uphold the teacher professional ethic code (Attachment of the Regulation of the Minister of 
National Education Number 16 Year 2007 Concerning Standard of Academic Qualification and Teacher Competence).

The third competence-social competence, as elaborated as well in the same regulation, requires teachers to be inclusive, objective, and non-discriminatory to any aspects, i.e. gender, religion, race, physical condition, family background, and socioeconomic status; to communicate effectively, empathically, and courteously with fellow teachers, educative personnel, parents, and the community; to be adaptable with the working place throughout the territory of the Republic of Indonesia which has a socio-cultural diversity; and to communicate well with intra- and inter-profession community orally, in written or in other forms of communication.

As described as well in the same regulation, the last competence-the professional competence, includes the abilities to master the materials, structures, concepts, and scientific reasoning which supports the subject taught; to master the competence standard and basic competence of the subject taught; to develop learning materials creatively; to keep developing professionalism through reflective activities; and to use information communication technology (ICT) to communicate and further their own potentials.

The four teacher competences above are holistic in nature, meaning that all the competences have to be developed as whole. Thus, a professional English teacher is not the one who is just pedagogically and professionally competent. However, he/she is to be socially and personally competent as well. By obtaining the academic qualification and developing the teacher competences, an English teacher has helped him-/herself to be a quality teacher. The goal of professional development is to improve the quality of service provided-teachers' skills, values and practice, in the interests of clients (Gulti, 2010: 38).

In addition to the development of the four aspects of competences, professional teachers are also required to join a professional organization with the authority to regulate teachers. The Association of Teaching English as a Foreign Language in Indonesia (TEFLIN), for instance, is a non-benefit organization an English teacher should join. This association was founded with the aim of promoting the quality of teaching English in Indonesia. Joining a professional association for English teachers is a good start for furthering their career. Cherwin (2010) shows three benefits someone can obtain from an association: 1) enhancing network that gives a sense of security and trust from which he/she can support and help one another in reaching his/her professional goals; 2) taking advantage of the career resources such as job offer, experts that can be contacted for specific questions on career issues, and information about seminars, training, or certification classes, and 3) learning more or staying informed about issues in diversity.

\section{PROFESSIONAL REWARD}

When an English teacher completes his/her certification and passes the exam, he/she receives a teaching certificate as the formal evidence that he/she is legitimately recognized as a certified, professional teacher. With such a status, what benefit can an English teacher take from his/her successful certification? First of all, he/she deserves to feel proud of himself/herself for being recognized as a certified teacher. Second, he/she deserves to receive the professional reward, 
that is, the professional allowance granted by the government regularly. Dealing with professionals in their book chapter entitled "The Status of Teaching as a Profession", Ingersoll \& Perda (2008: 113) argue:

Professionals typically are well compensated and are provided with relatively high salary and benefit levels throughout their career span. The assumption is that, given the lengthy training and the complexity of the knowledge and skills required, relatively high levels of compensation are necessary to recruit and retain capable and motivated individuals.

The post-certification reward is regulated in Government Regulation Number 19 Year 2017 on Amendment to Government Regulation Number 74 Year 2008 Concerning Teachers. In Article 15 Section 4 it is stated that professional allowance is granted to a teacher who: "has 1 (one) or more teaching certificates, has a teacher registration number, meet the workload, teaches actively as a subject teacher and/or a classroom teacher in a school in line with his/her teaching certificate, is not more than 60 years old, is not tied up as a permanent teacher to the other school other than the assigned institution, has at least good score of teaching performance, and teaches in class in accordance with teacherstudent ratio." (p.3)

Professional reward should stimulate an English teacher to be highly motivated to present better learning services to his/her students. By so doing, he/she can increase his/her trust in the eyes of the students, parents, and the society. The trust from the stakeholders increases his/her self-confidence in teaching. It also helps him/her develop a market for his/her professional services. The more he/she earns, the stronger his/her professional survival is.

Besides, a certified, professional English teacher should realize that he/she plays a central role in improving the learning quality. Gordon et al. (2009: 168) in "Key Competences in Europe: Opening Doors for Lifelong Learners Across the School Curriculum and Teacher Education" (CASE Network Reports No. 87) argue that teachers are a key agent in the successful implementation of competence-based education. They need to feel appreciated about this role. A similar view comes from "Teachers Matter", a 2005 report from OECD (OECD, 2005cited in Donaldson, 2013: 13), which shows a wide body of research evidence which suggested that teacher quality was one of the most significant factors affecting successful student learning. Students from disadvantaged families may benefit the most from learning with high-quality teachers (Hanushek, 1992; Nye et al., 2004; Sanders and Rivers, 1996 cited in Looney, 2015: 3). Similarly, a highly influential report of the McKinsey Corporation (McKinsey, 2007, cited in Donaldson, 2013: 13), reinforces the centrality of teacher quality in the world's best performing school systems.

To summarize, having received the teaching certificate to legitimate his/her status as professional teacher, an English teacher needs to continue developing his/her professionalism. This is done in return for his/her receiving the professional reward. Developing professionalism sustainably increases his/her degree of professionalism. Conversely, if professional reward does not make any productive changes in his/her teaching behavior, he/she deserves not to receive the 
reward anymore. "If teachers have a high probability of being rewarded without any change in their behavior, the mechanism no longer provides any incentive to improve teaching and learning" (Vegas \& Petrow, 2008 cited in Sia, 2012: 19). The necessity to grant sanction to the teachers who are unable to develop their professionalism is highlighted in Government Regulation Number 74 Year 2008 Concerning Teachers. Article 63 Section 1 of this regulation writes, "Teachers who cannot meet the academic qualification, competence, teaching certificate ... lose the right to get functional allowance or functional allowance subsidy, and additional benefits." (p. 42).

\section{FURTHER PROFESSIONAL DEVELOPMENT}

An English teacher who has passed teacher certification and received teaching certification should not think that he/she has finished his/her professional development and thus does not need to continue developing his/her professionalism. Instead, he/she has to think that what he/she has done is not more than fulfilling the professional standard as demanded. That is why he/she has to keep developing his/her professionalism above and beyond the standard.

Over time professionalization leads professionals to develop a market for their services, to define who is competent to provide these services, to restrict their numbers by imposing ever-higher entrance qualification requirements, and to achieve the exclusive legal right to supply these services (Hoyle \& John, 1995: 7 cited in Gulti, 2010: 38). Through these, the professionals assure themselves of job security, social prestige and the ability to demand higher salary levels. The further they elevate their professionalism, the more they receive professional appreciation (promotion, trust, additional tasks, additional benefits, etc.). Thus, professional teachers should continue developing their professionalism and negate John Hattie's meta-analysis of research evidence (Hattie, 2009 cited in Donaldson, 2013: 14) which suggests that up to eighty-five per cent of teachers are resistant to changing their existing practice.

What does a certified English teacher need to develop further? He/she has to develop further the four holistic domains of his/her competence: pedagogical, professional, social and personality competence. Professionalism is a matter of degree. To be more professional, he/she has to make him/herself a life-long learner who is highly committed to keep empowering himself/herself by deepening his/her professional competence. He/she has to be more knowledgeable about the substance of his/her teaching (language teaching and learning principles, language skills and components, language testing/assesment, and the English teaching syllabus innovation).

$\mathrm{He} / \mathrm{she}$ has also to be highly committed to continue deepening his/her pedagogical competence. He/she has to be more skillful in presenting more quality, creative, innovative, conducive, and thus enjoyable learning for his students through the use of updated learning materials, current hardware and software of teaching media, more productive learning atmosphere, and current teaching approach such as scientific approach with inquiry, problem-based, project-based, and problem-solving techniques.

To make their self-empowerment holistic, English teachers also need to further their personality and social competence. English teachers today are demanded not only to be able to know more about what to teach and how to teach 
but also about how to behave as role models and how to extend better relationship and collaboration across networks. This is in line with "the seven survival skills for careers, college, and citizen" as introduced by Tony Wagner (2008), namely (1) critical thinking and problem-solving, (2) collaboration across networks and leading by influence, (3) agility and adaptability, (4) initiative and entrepreneurialism, (5) effective oral and written communication, (6) accessing and analyzing information, and (7) curiosity and imagination. Similar categories (four broad categories) are proposed by more than 250 researchers across 60 institutions worldwide who met in the Assessment and Teaching of 21st-Century Skills project (Schleicher, 2012: 34, Saavedra, 2012: 4-5, see also Pacific Policy Research Center, 2010) as follows:

a. Ways of thinking. Creativity, critical thinking, problemsolving, decision-making and learning.

b. Ways of working. Communication and collaboration.

c. Tools for working. Information and communications technology (ICT) and information literacy.

d. Skills for living in the world. Citizenship, life and career, and personal and social responsibility.

These skill categories entail some ideas for teaching. Concerning ways of thinking and ways of working, English teachers today are demanded to apply scientific approach and thematic integrative approach which call for discovery/inquiry based learning, problem-based learning, project-based learning, and cooperative learning to enable the learners to develop their higher order thinking skills (HOTS) (see the Attachment of Regulation of the Minister of Education and Culture Number 22 Year 2016 Concerning Process Standard of Primary and Secondary Education, p.3).

In connection with the tools for working, English teachers today are encouraged to use technology to transform assessment systems and learning. Concerning the use of ICT in teaching, Anita Lie (2017: 87), who is concerned very much with the current education phenomena that today in schools and at homes learners can tap into numerous on-line resources to complement or to substitute for what is missing in the English classrooms, reminds the teachers for furthering their roles as learning managers and facilitators in order to be able to design and deliver e-learning or blended learning for more effective English language teaching. A motivation to use technology in teaching also comes from Sankó (2015: 169), who elaborates the new Web 2.0 technologies in his book chapter, "Web 2.0: Ways to learn/teach a second language". The new Web 2.0 technologies allow students not only to be the consumers of content as in the case of printed textbooks but also the generators of content. Under the new Web 2.0 technologies, Google can be used not only as a web browser but also as a tool for sharing documents (GoogleDoc) and communicating (Gmail)and as a range of other useful applications such as Skype, blogs, wikis, Facebook, YouTube, etc. All these user-friendly tools are based on social networking so that they emphasize collaboration among their users; they facilitate teachers and students to participate actively in the learning process. This enables them to generate and propose contents, stimulate discussion, and create real learning communities. 
Last but not least, concerning skills for living in the world, English teachers today are required not only to teach English language components and skills but also demanded to develop the learners' spiritual and social attitude. This demand is manifested in the Attachment of Regulation of the Minister of Education and Culture Number 21 Year 2016 Concerning Contents Standard of Primary and Secondary Education, in particular in the formulation of the core competence 1 (spiritual attitude) and core competence 2 (social attitude).

\section{CONCLUSION}

Teaching English in Indonesia offers both challenges - the professional demand and the professional benefits. Once an individual has made a choice to be an English teacher, he/she should not hesitate to keep his/her choice. Becoming an English teacher is not a bad luck but an honorable, glorious decision in life. Perceiving teaching profession as a call, or a vocation, not a burden of life, strengthens his/her motivation and commitment for furthering his professionalism which leads him/her to professional survival. The stronger the survival, the more professional rewards he/she deserves to receive.

\section{REFERENCES}

Brown, H. D. (2007). Principles of language learning and teaching (5th ed.) New York: Pearson Education, Inc.

Cherwin, K.A. 2010. Why Join a Professional Association? State College: HigherEdJobs. Retrieved from https://www.higheredjobs.com/articles/articleDisplay.cfm?ID=157

Cobbold, C. (2015). Professionals without a profession? The paradox of contradiction about teaching as a profession in Ghana. Journal of Education and Practice, 6 (6), 125-134. Retrieved from http://files.eric.ed.gov/fulltext/EJ1083583.pdf

Crystal, D. (2003). English as a global language. (2nd ed.) Cambridge: Cambridge University Press.

Deliusno (2016). Tekno e-business: PNS jadi profesi dengan tingkat kepuasan tertinggi. Kompas.com, 25/07/2016, 19:10 WIB. Retrived from http://tekno.kompas.com/read/2016/07/25/19100017/PNS.Jadi.Profesi.den gan.Tingkat Kepuasan.Tertinggi.

Donaldson, G. (2013). The twenty-first century professional. In VlastaVizekVidović\&Zoran Velkovski (Eds.), Teaching profession for the 21st century: Advancing teacher professionalism for inclusive, quality and relevant education - ATEPIE (pp. 13-23). Belgrade: Centre for Education Policy.

Farrell, T. (2015). Promoting teacher reflection in second language education. New York: Routledge.

Gordon, J., Halász, G., Krawczyk, M., Leney, T., Michel, A., Pepper, D., Putkiewicz, E., \& Wiśniewski, J. (2009). Key Competences in Europe: Opening Doors for Lifelong Learners Across the School Curriculum and Teacher Education. CASE Network Reports No. 87. Warsaw: CASE Center for Social and Economic Research. doi: 
https://ssrn.com/abstract $=1517804$

or http://dx.doi.org/10.2139/ssrn.1517804.

Gulti, J. (Ed.). (2010). Being a teacher: Professional challenges and choices Learning guide. Braamfontein: Saide. Retrieved from www.oerafrica.org/system/files/8801/being- teacher guideb_0.pdf?file=1\&type.

Ingersoll, R.M., \&Perda, D. (2008). The status of teaching as a profession. In Jeanne Ballantine \& Joan Spade (Eds.), Schools and Society: A sociological approach to education (Chapter 12, pp. 106-118). Los Angeles: Pine Forge Press.

Lampiran Peraturan Menteri Pendidikan dan KebudayaanRepublik Indonesia Nomor 21 Tahun 2016. Standar Isi Pendidikan Dasardan Menengah. 28 Juni 2016. Berita Negara Republik Indonesia Tahun 2016 Nomor 954. Jakarta.

Lampiran Peraturan Menteri Pendidikan dan Kebudayaan Republik Indonesia Nomor 22 Tahun 2016. Standar Proses Pendidikan Dasar dan Menengah. 6 Juni 2016. Berita Negara Republik Indonesia Tahun 2016 Nomor 955. Jakarta.

Latief, M. (2016). News edukasi: Rp 3 jutaan... "segitulah" rata-rata gaji guru dan dosen Indonesia! Kompas.com, 03/05/2016, 16:25 WIB. Retrieved from http://edukasi.kompas.com/read/2016/05/03/16255571/Rp.3.Jutaan.Segitul ah.Rata-rata. Gaji.Guru.dan.Dosen.Indonesia.

Lie, A. (2017). English and identity in multicultural contexts: Issues, challenges, and opportunities. TEFLIN Journal, 28 (1), 71-92. doi: http://dx.doi.org/10.15639/teflinjournal.v28i1/71-92

Looney, J. (2015). International Trends in Teacher Appraisal by The European Institute of Education and Social Policy. Background paper for discussion at the 12th Session of the CEART held inParis, 20-24 April 2015. Geneva: International Labour Office and United Nations Educational, Scientific and Cultural Organization. Retrieved from http://www.ilo.org/wcmsp5/groups/public/---eddialogue/--sector/documents/meetingdocument/wcms_364841.pdf

Peraturan Menteri Pendidikan dan Kebudayaan Republik Indonesia Nomor 29 Tahun 2016. Sertifikasi bagi guru yang diangkat sebelum tahun 2016. 24 Agustus 2016. Berita Negara Republik Indonesia Tahun 2016 Nomor 1264. Jakarta.

Peraturan Menteri Pendidikan Nasional Republik Indonesia Nomor 16 Tahun 2007. Standar kualifikasi akademik dan kompetensi guru. 4 Mei 2007. Jakarta.

Peraturan PemerintahNomor 74 Tahun 2008. Guru. 1 Desember 2008. Lembaran Negara Republik Indonesia Tahun 2008 Nomor 194. Jakarta.

Pacific Policy Research Center. (2010). 21st century skills for students and teachers. Honolulu: Kamehameha Schools, Research \& Evaluation Division.

Peraturan Pemerintah Republik Indonesia Nomor 19 Tahun 2017. Perubahan atas peraturan pemerintah nomor 74 tahun 2008 tentang guru. 2 Juni 2017. Lembaran Negara Republik Indonesia Tahun 2017 Nomor 107. Jakarta. 
Pusat Data danStatistik Pendidikan danKebudayaan (PDSPK), Kementerian Pendidikan dan Kebudayaan (Kemendikbud). (2017). Ikhtisar data pendidikantahun 2016/2017.Jakarta: PDSPK Kemendikbud.

Saavedra, A.R., \&Opfer, V.D. 2012. Teaching and learning 21st century skills: Lessons from the learning sciences. Hong Kong: Asia society.

Sankó, G. (2015). Web 2.0: Ways to learn/teach a second language. In Challenges of the 21st century: An in-service teacher training course for EFL teachers (pp. 167-196). Debrecen: Debrecen University Press.

Schleicher, A. (Ed.). (2012). Preparing teachers and developing school leaders for the 21st century: Lessons from around the world. OECD Publishing. http://dx.doi.org/10.1787/9789264174559-en.

Sia, L. (2012). Comprehensive teacher education policies and quality assurance standards: initial, in-service and continual teacher education in lifelong perspectives. A paper served as a background study for the 11th session of the Joint ILO/UNESCO Committee of Experts on the Application of the Recommendations concerning Teaching Personnel (CEART) held in Geneva 8-12 October 2012. Geneva: International Labour Office and United Nations Educational, Scientific and Cultural Organization. Retrieved from www.ilo.org/sector/Resources/publications/WCMS_214159/lang-en/index.htm.

Undang-Undang Republik Indonesia Nomor 14 Tahun 2005. Guru dan dosen. 30 Desember 2005. Lembaran Negara RI Tahun 2005 Nomor 157. Jakarta.

Wagner, T. (2008). The global achievement gap: Why even our best schools don't teach the new survival skills our children need and what we can do about it. New York: Basic Books. 